\title{
Mono- and polychromatic inner shell phenotype diversity in Pinctada margaritifera donor pearl oysters and its relation with cultured pearl colour
}

\author{
Ky Chin-Long ${ }^{1,{ }^{*}}$, Lo Cedrik ${ }^{2}$, Planes Serge ${ }^{3}$
}

${ }^{1}$ Ifremer, UMR 241, EIO, Labex Corail, Centre du Pacifique, BP 7004, 98719 Taravao, Tahiti -

Polynésie Française

2 Direction des Ressources Marines et Minières, BP 20, 98713 PAPEETE, TAHITI, Polynésie Française

${ }^{3}$ EPHE, PSL Research University, UPVD, CNRS, USR 3278 CRIOBE, F-66360 Perpignan, France

*Corresponding author : Chin-Long Ky, email address : chinky@ifremer.fr

\begin{abstract}
:
The pearl oyster Pinctada margaritifera has the specific ability to produce pearls with the widest range of colours among all pearl oyster species. This pearl colour diversity originates from the mantle biomineralising tissue (graft) of the donor oyster, which is originally responsible for the variety of colours of the inner shell surface. This study aimed to: 1) assess the geographic distribution and establish a first stocklist of the colourful oyster phenotypes used as donors in French Polynesia, and 2) investigate the phenotypic relation between inner shell colouration and the corresponding colour of harvested pearls. With the support of a pearl farmers' network, we investigated the different donor phenotype frequencies among five collection sites (Ahe, Apataki, Takaroa, Takume and Mangareva). This donor evaluation was made during grafting of pearl oysters $(\mathrm{N}=49,938)$ obtained from collector stations. Results showed that pearl production is mainly based on six common colourful donor phenotypes classified as monochromatic and polychromatic profiles, which shown different frequencies among the collection sites. Experimental grafts $(\mathrm{N}=4640)$ were then realised and subsequent culture conducted at a single site in order to avoid pearl colour variation due to environmental influences. Traceability between donors $(\mathrm{N}=232$ ) and pearls $(\mathrm{N}=2776)$, revealed that: 1 ) yellow (gold) and aubergine (reddish) pearls could be mostly obtained by using the monochromatic yellow and red donor phenotypes, respectively, and 2) one third to one quarter of grey pearls was inevitably harvested, whatever the polychromatic phenotype chosen as the donor, which leaves at least half the harvest composed of the attractive green and peacock colours. This preliminary stocklist of colour range together with analysis of the colour phenotype transmission between inner shell and pearl provide the basis for producing multiple pearl oyster "colour lines" through hatchery propagation and would be helpful for future selective breeding programs.
\end{abstract}

Statement of relevance. Donor shell colour selection predict colours of pearls

Keywords: Pearl oyster, Pinctada margaritifera, Shell colour, cultured pearl colour, phenotypes, Diversity 


\section{Introduction}

The marine mollusc Pinctada margaritifera is widely distributed in shallow IndoPacific tropical and subtropical waters, and is mostly associated with reef environments (L. Cunha et al., 2010). This pearl oyster is the primary aquaculture species in French Polynesia, where the pearl industry represents the second most important source of income, just after tourism. This aquaculture is based on natural spat collection from wild stocks, that mainly originated from five lagoons located in the atolls Ahe, Apataki, Takaroa and Takume (Tuamotu archipelago), and Mangareva Island (Gambier archipelago). This natural production resource supplied (boat and plane transfers) the 517 pearl farms located on 26 atolls and islands in Tuamotu (398 farms), Gambier (79 farms), and Society (40 farms) (Talvard, 2015). For the cultured pearl production, a grafting process is required, which consists of the introduction of a nucleus (a bead made from the shell of a fresh-water bivalve) and a graft (a piece of mantle tissue from a selected donor oyster) into the gonad of a recipient oyster (Alagarswami, 1970).

A remarkable specificity of the $P$. margaritifera pearl oyster is its ability to produce a very wide range of pearl colours (Ky et al., 2014b). These colours range from the purest white to the deepest black, and include every shade of silver, peacock, green, aubergine, purple, golden brown and even rainbow. Pearl colours are not as diverse in the two other pearl oyster species also used in aquaculture, $P$. fucata martenseii (pink, white or silver, cream and yellow) and P. maxima (golden, silver-white, yellow or cream) (Tong and Shen, 2001; Taylor and Strack, 2002). Although only a few studies have been made on transmissions between donor phenotypes and pearl colours in P. margaritifera, these relations have been demonstrated through experimental grafting designs using both wild (Tayale et al., 2012) and hatchery-produced (Ky et al., 2013; 2016a) donor oysters. More recently, Ky et al. (2015a) also observed correlations between the outer (prismatic layers) and inner (nacreous layers) 
shell colours of donors and the colour proportions observed in the harvested pearls. In the close related species $P$. fucata, Wada and Komaru (1996) observed an association between donor shell and pearl colour. In xenografts involving $P$. maxima and $P$. margaritifera species, McGinty et al. (2010) demonstrated conclusively that the donor oyster is the primary determinant of pearl colour.

Throughout the distribution of $P$. margaritifera in French Polynesia, only a small proportion of pearl oysters are selected as donors for cultured pearl production. Usually, only the individuals with the most colourful inner shell sides are chosen to be donors; the others commonly have grey-dark coloured bands and are used as recipients. Desirable donor oysters with particular phenotypes show relatively low frequencies at the population level. Phenotype is defined as an observable characteristic of an individual or population that is determined by their genes or a combination of their genes and the environment. A phenotype is the expressed state of a given trait, which may either have distinct categories, as in simple Mendelian qualitative traits or polygenic traits with an underlying threshold that determines the phenotype, or be quantitative, with many possible values along a continuous scale. Some rare colour phenotypes have been recently reported in $P$. margaritifera, with a Mendelian inheritance for orange flesh, and red and white shell colours, compared with the wildtype black flesh and shell commonly found in this species (Ky et al., 2016b). Some phenotypes can be particularly advantageous because of their local adaptation to the constraints of their specific environment (e.g. excessive heat, endemic diseases), which improves not only their survival capacity but also their performance. Understanding the variability in the inheritance and the transmission of the colour phenotype is essential for the future development of the pearl aquaculture.

The aim of this study was to undertake an inventory of the rare pearl oyster inner shell colour phenotypes commonly used as donors in the cultured pearl industry in French 
Polynesia. For this, a pearl farmers' support network (who obtain their pearl oysters from the collection sites) allowed us to sample and estimate the frequencies of the main donor oyster phenotypes used in French Polynesia. A sample of these donors was used in large experimental graft, grown on in a single culture site as a means to establish a first stocklist detailing the close relation between inner shell and pearl colour phenotypes. This stocklist will provide a basis for breeding multiple donor oyster lines to produce pearls of specific colours that could be established in breeding programme. 


\section{Materials and methods}

\section{Wild donor pearl oyster collection and selection}

Pearl oysters aged around 20 months old $(7-9 \mathrm{~cm})$ were selected from collectors from the five main wild seed collection areas located in Ahe, Apataki, Takaroa, Takume atolls (Tuamotu Archipelago) and Mangareva Island (Gambier Archipelago) in July 2013 (Map in Fig. 1). Access to these oysters of broad geographic origin was obtained through a pearl farm network. This network is composed of five pearl farms that get their oyster stock from the five collection sites (Table 1). Indeed, wild saibo donor and recipient were collected as spat in the lagoon of these sites. Passive techniques were employed for catching spat using commercial collectors made from modern synthetic materials, to which planktonic mollusc larvae become attached fifteen to twenty days after their release. The technique consists of immersing a rope at a depth of $3 \mathrm{~m}$, which is stretched out between buoys and moored to pinnacles or dead weights placed on the lagoon floor. Surface buoys keep the 100 to 200 metres rope suspended off the bottom. Collectors were attached at roughly one meter intervals. After nearly one year of subsurface rearing (3-5m below the surface), the collectors were transferred by boat from the collection site to the pearl farm and grown for 8 additional months. During the graft process in each of the pearl farms, the oysters were removed from the collectors on which they had developed.

Selection of the pearl oyster was made by expert grafters and followed a two-step procedure. In the first stage, the grafter selects a healthy pearl oyster, which is identifiable by colour of the visceral mass and gills (brilliant appearance), shell size and appearance (round shape suggesting a regular growth), and muscle resistance when opening the shells. In the second step, each oyster was checked for its inner shell colour phenotype by using a speculum to open the valves from the set of healthy pearl oysters. A dentist's mirror was inserted into the 
open oyster to be able to see the inner shell colouration, and particularly the contact area (band colour) with the mantle at the edge of the shell. Other inner shell area, that was not in contact with the mantle, exhibited a white colour, characteristic of $P$. margaritifera. Oysters with a yellowish and reddish band colour were selected and classified according to their phenotypes. Among these colourful pearl oyster, six phenotypes has been selected: 1) the yellow band, 2) the yellow band with additional green pigment, 3) the yellow band with green and additional red pigment, 4) the red band, 5) the red band with additional green pigment and 6) the red band with green and additional red pigment (Fig. 2). The un-colourful band colour corresponded to non-selected oysters, which exhibited a grey to black colour. From the five collection sites, a total of 49938 pearl oysters has been randomly screened for their colours (Fig. 2). The proportions of "selected" vs. "non-selected" phenotypes were evaluated for each of the collection sites to establish a stocklist of donor used for the graft in French Polynesia pearl oyster aquaculture. Based on this stocklist, samples of the donor oysters representing each of the selected phenotypes and originating from each of the collection sites were transferred by plane to Arutua atoll (Pommier pearl farm, Tuamotu Archipelago), where experimental grafts were performed three months later (October 2013) to test the transmission of characters from the donor to the final pearl product.

\section{Experimental graft}

The experimental graft was performed on Arutua atoll (Pommier pearl farm, Tuamotu Archipelago). The donor pearl oysters were opened individually. Where possible, eight donor oysters per phenotype and per collection site $(\mathrm{N}=5)$ were used. The epithelial cells required for the grafting procedure were excised from the mantle by an expert grafter. Small squares of epithelium ("grafts") measuring approximately $4 \mathrm{~mm}^{2}(\mathrm{~N}=20$ per donor oysters) were prepared before being transplanted into the recipient oysters (issued from a single batch of 
healthy oysters). Another grafter cut out a hollow in the recipient "oyster" gonad into which they then placed the nucleus and graft. The nuclei used were all similar and imported from Japan: 2.4 BU nucleus (7.304 mm diameter, 0.59 g weight - Nucleus Bio, Hyakusyo Co. Japan). The whole grafting operation takes approximately 1 minute (Ky et al, 2014b). A total of 4640 grafts were performed over a 6-days period. Traceability of donor oysters was maintained by using numbered plastic labels attached to the chaplets, where the corresponding recipient oysters were reared. After 18 months of culture (April 2015), the cultured pearls were harvested and assessed for their colour.

\section{Cultured pearl colour}

Cultured pearls were cleaned by ultrasonication in soapy water (hand washing) with a LEO 801 laboratory cleaner (2-L capacity, $80 \mathrm{~W}, 46 \mathrm{kHz}$ ); they were then rinsed in distilled water. Colour evaluation (without a jeweller's loupe) was made on the cultured pearls according to Ky et al. (2013) by two operators working in cooperation. The visually-perceived colour (bodycolor), due to pigments, and secondary colour (overtone) were recorded as categories. Six colour categories were established into which all the harvested pearls could be classified: 1) samples with dominance of bodycolors (without an overtone): grey, white and yellow, and

2) samples with additional secondary colours (moderate to distinct overtones): green, aubergine (red / purple), and peacock (a mix of aubergine and green).

\section{Statistical analysis}

Fisher's exact tests for count data were performed to check whether there was a difference in the inner shell colouration phenotype distributions among collection sites or a difference in cultured pearl colour categories issued from different donor phenotypes. Data were analysed using R software version 3.1.0 (2014-01-10). 


\section{Results}

\section{Donor oyster colour phenotype diversity (i.e. the stocklist)}

Among the five collection sites that supply the French Polynesian pearl industry, six coloured inner shell phenotypes were recorded that are used as donors (Fig. 2). These phenotypes could be divided into two categories: 1) monochromatic phenotypes, which mainly had a single colour pattern (yellow and red), and 2) polychromatic phenotypes, which showed multiple superimposed colours, over yellow and red bases. The polychromatic yellow1 and red1 were characterised by an additional green band colouration, over the corresponding monochromatic base. The polychromatic yellow 2 and red 2 corresponded to a "second" additional red band colouration, over the corresponding yellow1 and red1 phenotypes. In addition, all the yellow and red phenotypes, whatever their monochromatic or polychromatic bases, exhibited respectively black and red outer shell colouration (Fig. 2).

Occurrence of these donor phenotypes revealed that they are found: 1) whatever the collection site, and 2) at low frequencies compared with the wild type inner shell phenotype (grey to black) (Table 1). A site-specific signature existed for the occurrence of different phenotypes among the collection sites. For the monochromatic phenotypes, the yellow and red variants were mostly found in north Tuamotus: Ahe, Takaroa and Apataki atolls, with a less of the yellow colouration for the latter. By contrast, Mangareva and Takume sites had the lowest rate of these monochromatic phenotypes.

For the polychromatic phenotypes, yellow1 phenotypes were mostly found in Mangareva, whereas red 1 and red 2 phenotypes were a specificity of Tuamotus atolls. The polychromatic yellow2 phenotype was very rare in Mangareva lagoon.

\section{Cultured pearl colour diversity}


The harvested pearls were classified according to colour categories for each of the donor colour phenotypes. Table 2 shows the distribution of the pearl colour among the six visual categories (grey, green, peacock, aubergine, yellow and white).

Pearls resulting from monochromatic donor phenotypes exhibited the lowest colour diversity, with a direct correspondence between inner shell and pearl colours (Fig. 3). The extreme was the monochromatic red phenotype used as donor that produce $100 \%$ red cultured pearls (Table 2). By contrast, the yellow phenotype produced yellow pearls, but also a diversity of other phenotype including a small proportion of white (8.6\%) (Table 2).

Pearl colour frequencies differed among the polychromatic phenotype used as donors. First, whatever the polychromatic phenotype considered, all produced at least some grey pearls: from one quarter to one third of the harvest (Table 2). For the other pearl colours, a correspondence existed between inner shell colour and pearl colour. Indeed, green pearls were predominately found after having used the polychromatic red1 and yellow2 phenotypes as donors. Peacock and aubergine pearls were mainly found when the polychromatic red2 phenotype was used as donor. Nearly one quarter of the total harvested pearls showed a yellow colour when the polychromatic yellow1 phenotype was used as the donor (Table 2). The proportion of white pearls was low $(<3.1 \%)$ whatever polychromatic donor phenotype was considered. 


\section{Discussion}

Wild P. margaritifera pearl oysters chosen as donors from five seed collection sites in French Polynesia displayed six common colourful mono and polychromatic patterns. Results revealed that these inner shell phenotypes could be found in all collection sites, but at different frequencies; with monochromatic phenotypes being the rarest at all sites. In some molluscan species, cryptic colour and morphology are correlated with a particular habitat patch likely due to better survival rates potentially from predator avoidance or antipredator defences (Lindberg and Pearse, 1990). Such habitat specificity could explain the differences in the rates of red phenotypes between the Tuamotu sites and Mangareva (atoll vs. island), where the lowest rates of this colour phenotype were recorded (nearly 70 and 22 times less for the monochromatic red and polychromatic red2 phenotypes, respectively). This result is in accordance with a recent study dealing with the outer shell colouration phenotypes (Ky et al., 2015a), in which the red shell phenotype was more frequent in the Tuamotu archipelago, particularly in the Takaroa and Ahe atolls, than in Mangareva Island. Indeed, all red inner shell phenotypes (red, red1 and red2) exhibited red outer shell phenotypes.

Molluscan shell colour could be regulated by environmental factors such as light, salinity and climate (Cowie, 1990; Heath, 1975; Sokolova and Berger, 2000). For example, temperature is one of the significant factors maintaining shell colour polymorphism of the intertidal snail Batillaria (Miura et al., 2007). As shell colouration is related to shell structure, which resulted from the biomineralisation process, food availability and temperature could contribute to explaining the overall geographical phenotype variability. This is the case for $P$. margaritifera, where its distribution area in French Polynesia is subjected to disparate temperature regimes. Gambier archipelago is characterised by contrasting seasons with a large range of temperature variation $\left(21.3^{\circ} \mathrm{C}\right.$ to $28.8^{\circ} \mathrm{C}$ in 2012) due to its southern latitude (Fig. 1), 
compared with Society and North Tuamotu $\left(27.3^{\circ} \mathrm{C}\right.$ to $29.2^{\circ} \mathrm{C}$ in 2012). Joubert et al. (2014) tested combinations of temperature and microalgal concentrations over a period of two months, revealing that the expression levels of Pif 177 and shematrin 9 were higher with a high microalgal concentration and that this was correlated with nacre deposition rate in $P$. margaritifera. For oyster shell growth, Linard et al. (2011) used microscopy to show that the thickness of the newly formed aragonite tables was thinnest for oysters that had been treated in a low trophic regime ( 800 cells/mL vs. 15000 cells/mL).

Inner shell colour inheritance has not yet been studied in P. margaritifera, but classification of the phenotypes here (Fig. 2) revealed different levels of colour superimposition that could be under simple genetic control in the same way as for outer shell colouration. For the yellow inner shell phenotypes (showing an all-black outer shell), the yellow1 phenotype had additional green colour to the yellow base. Then, the yellow2 phenotype had additional red colour to the yellow1 base (Fig. 2). In parallel, the same pattern existed for the red inner shell phenotypes (showing an all-red outer shell): the red1 phenotype had an additional green colour to the red base and red2 had an additional red colour to the red1 base. The variety of colour displayed is generally determined by just a handful of low molecular weight pigment compounds, or pyrrole-based pigments such as porphyrin (Hedegaard et al., 2006). These pigments are known to be under genetic control. In P. margaritifera, the Mendelian inheritance of outer shell colour variants has already been demonstrated, with a three-allele model where the black wildtype allele is dominant to the red colouration, which is dominant to the white shell (Ky et al., 2016b). Crossing experiments has been previously done in P. fucata on different outer shell phenotype (prismatic layer colouration), and have shown relatively simple genetic bases for colour trait inheritance. In this species, the red type may be dominant over the yellow type, which is dominant over other common type (Wada 1984). In addition, the white type is inherited under the control of 
recessive gene (Wada \& Komaru, 1900). In the same study, a relation between outer and inner shell has been observed, with the amount of yellow pigments (inner shell) smaller in white type (outer shell) specimens than in brown wild-type. Differences observed in the present study, particularly for the red phenotype, where the highest rate was recorded in Tuamotus atoll, could reflect genetic differentiation either through drift or via local selection, but not environmentally-driven plasticity. Pearl oyster transfer and culture in the North Tuamotus area, where the collection sites of Ahe, Apataki and Takaroa atolls are located, have probably contributed to explaining why the phenotype frequencies were similar.

For the first time in $P$. margaritifera, this study demonstrates the existence of a clear relation between inner shell colour phenotype of donor oysters and the colour of the pearl harvested. This was demonstrated by using the monochromatic phenotypes, where using yellow and red inner shell phenotypes as graft donors makes it possible to produce mainly gold and reddish pearls, respectively. As the grow-out environment of the recipients is known to play a key role in the final pearl colour achieved by harvest (Blay et al., 2016; Ky et al., 2015b; Le Pabic et al., 2016), the present study was realised in a single culture location with a batch of oysters of the same age to avoid any differential influence of rearing site or age on pearl colour distribution (Ky et al., 2015c). Knowledge on the potential correspondence between shell colour and pearl colour will be of practical use to breeders aiming to select and propagate pearl oysters for the production of specific pearl colours in P. margaritifera. However, all polychromatic shell phenotypes produced several pearl colours, among which the non-target a high rate of grey pearls was harvested (one quarter to one third of the total harvest). Grey pearls are commonly found at the production scale and is a specificity of the so called "black-lipped" pearl oyster species. Targeting the exclusive production of the attractive green and peacock colours would not be possible by these means. In other words, it would be difficult to minimise the rate of grey pearls by using wild donor pearl oysters. 
This preliminary stocklist opens the way for: 1) hatchery selection and propagation of specific oyster lines with desired shell colouration, which could potentially compete with other colour-specific pearl production in mollusc aquaculture; 2) transcriptomic analysis using next generation sequencing technologies (RNA-seq) to associate gene expression profiles with colour phenotypes for a better understanding of the molecular process underlying colour expression; 3) prospection for other interesting colourful phenotypes that could be recovered from other areas, where no pearl industry activity or oyster transfer has existed to date, such as in the Austral or in Marquesas archipelagos; and 4) ecological genetics investigations to understand the mechanisms maintaining population polymorphism under natural conditions.

\section{Acknowledgements}

This work was supported by grants from the Direction des Ressources Marines et Minières, through the ColoGEN project (2015-2017). We would especially like to thank the host site and employees of Pommier's Pearl Farm (Arutua atoll, Tuamotu archipelago, French Polynesia) for the generous support they provided for the experimental graft and provision of pearl oysters from Takaroa atoll. The authors also thank the pearl farm network comprising Pahai Poe (Apataki atoll), Heimoana Poe (Takume atoll), Regahiga (Mangareva Island) and Ahe Royal Pearl (Ahe atoll) for providing the biological specimens. 


\section{References}

Adamkewicz, L., Castagna, M., 1988. Genetics of shell color and pattern in the bay scallop Argopecten irradians. Journal of Heredity 79, 14-17.

Blay, C., Parrad, S., Cabral, P., Aiho, V., Ky, C.L., 2016. Correlations between cultured pearl size parameters and PIF-177 biomarker expression in Pinctada margaritifera families reared in two contrasting environments. Estuarine, Coastal and Shelf Science, in press, http://doi.org/10.1016/j.ecss.2016.05.020.

Cowie, R.H., 1990. Climatic selection on body color in the land snail Theba pisana (Pulmonata: Helicidae). Heredity 65, 123-126.

Gervis, M.H., Sims, N.A., 1992. The biology and culture of pearl oysters (Bivalvia: Pteridae). ICLARM Stud. Rev. 21, ODA (Pub), London. pp 49

Hedegaard, C., Bardeau, J.F., Chateigner, D., 2006. Molluscan shell pigments: An in situ resonance Raman study. J Molluscan Stud, 72: 157-162.

Joubert, C., Linard, C., Le Moullac, G., Soyez, C., Saulnier, D., Teaniniuraitemoana, V., Ky, C.L., Gueguen, Y., 2014. Temperature and Food Influence Shell Growth and Mantle Gene Expression of Shell Matrix Proteins in the Pearl Oyster Pinctada margaritifera. PLoS ONE, Vol. 9, Issue 8. 
Ky, C.L., Blay, C., Sham-Koua, M., Vanaa, V., Lo, C., Cabral, P., 2013. Family effect on cultured pearl quality in black-lipped pearl oyster Pinctada margaritifera and insights for genetic improvement. Aquatic Living Resources, 26, 133-145.

Ky, C.L., Blay, C., Sham Koua, M., Lo, C., Cabral, P., 2014a. Indirect improvement of pearl grade and shape in farmed Pinctada margaritifera by donor "oyster" selection for green pearls. Aquaculture, 432, 154-162.

Ky, C.L., Molinari, N., Moe, E., Pommier, S., 2014b. Impact of season and grafter skill on nucleus retention and pearl oyster mortality rate in Pinctada margaritifera aquaculture. Aquaculture International, 22, 1689-1701.

Ky, C.L., Le Pabic, L., Sham Koua, M., Molinari, N., Nakasai, S., Devaux, D., 2015a. Is pearl colour produced from Pinctada margaritifera predictable through shell phenotypes and rearing environments selections? Aqua Research doi: http://doi.org/10.1111/are.12947

Ky, C.L., Blay, C., Aiho, V., Cabral, P., Le Moullac, G., Lo, C., 2015b. Macro-geographical differences influenced by family-based expression on cultured pearl grade, shape and colour in the black-lip pearl oyster Pinctada margaritifera : a preliminary case study in French Polynesia. Aquaculture Research, http://doi.org/10.1111/are.12880

Ky, C.L., Demmer, J., Blay, C., Lo, C., 2015c. Age-dependence of cultured pearl grade and colour in the black-lipped pearl oyster Pinctada margaritifera. Aqua Research doi: 10.1111/are. 12938 
Ky, C.L., Blay C., Lo C., 2016a. Half-sib family effects on cultured pearl quality traits in the black-lipped pearl oyster Pinctada margaritifera: testing for indirect benefits of polyandry and polygyny. Aquaculture International, 24(1), 171-182. http://doi.org/10.1007/s10499-015-9917-4

Ky, C.L., Nakasai, S., Pommier, S., Sham Koua, M., Devaux, D., 2016b. The Mendelian inheritance of rare flesh and shell colour variants in the black-lipped pearl oyster (Pinctada margaritifera). Animal Genetics, 47, 610-614.

L. Cunha, R., Blanc, F., Bonhomme, F., Arnaud-Haond, S., 2010. Evolutionary patterns in pearl oysters of the Genus Pinctada (Bivalvia: Pteriidae). Marine Biotechnology, 13 (2), 181-192.

Le Pabic, L., Parrad, P., Sham Koua, M., Nakasai, S., Saulnier, D., Devaux, D., Ky, C.L., 2016. Culture site dependence on pearl size realization in Pinctada margaritifera in relation to recipient oyster growth and mantle graft biomineralization gene expression using the same donor phenotype. Estuarine, Coastal and Shelf Sci doi: 10.1016/j.ecss.2016.03.009

Linard, C., Gueguen, Y., Moriceau, J., Soyez, C., Hui, B., Raoux, A., Cuif, J.P., Cochard, J.C., Le Pennec, M., Le Moullac, G., 2011. Calcein staining of calcified structures in pearl oyster Pinctada margaritifera and the effect of food resource level on shell growth. Aquaculture, 313, 149-155. 
Lindberg, D.R., Pearse, J.S., 1990. Experimental Manipulation of Shell Color and Morphology of the Limpets Lottia-Asmi (Middendorff) and Lottia-Digitalis (Rathke) (Mollusca, Patellogastropoda). J Exp Mar Bio Ecol., 140: 173-185.

McGinty, E.L., Evans, B.S., Taylor, J.U.U., Jerry, D.R., 2010. Xenografts and pearl production in two pearl oyster species, $P$. maxima and P. margaritifera : Effect on pearl quality and a key to understanding genetic contribution. Aquaculture, 302, 175-181.

Miura, O., Nishi, S., Chiba, S., 2007. Temperature-related diversity of shell color in the intertidal gastropod Batillaria. Journal of Molluscan Studies 73, 235-240.

Sokolova, I.M., Berger, V.J., 2000. Physiological variation related to shell colour polymorphism in White Sea Littorina saxatilis. J Exp Mar Bio Ecol., 245: 1-23.

Talvard, C., 2015. Bilan, la perle en 2013. In: Points Forts de la Polynésie Française (ed. by S. Challier), pp 1-5. Institut de la Statistique en Polynésie Française, Papeete, Polynésie Française.

Tayale, A., Guegen, Y., Treguier, C., Le Grand, J., Cochennec-Laureau, N., Montagnani, C., Ky, C.L., 2012. Evidence of donor effect on cultured pearl quality from a duplicated grafting experiment on Pinctada margaritifera using wild donors. Aquatic Living Resources 25, 269-280.

Taylor, J., Strack, E., 2002. The pearl oyster: biology and culture (pearl production). The Netherlands: Elsevier 15, 273-302. 
Tong, Y., Shen, H., 2001. Quality assessment and testing of akoya pearls. China Gems and Jades 1, 68-69.

Wada, K.T., 1984. Breeding study of the pearl oyster, Pinctada fucata. Bull. Natl. Res. Inst. Aquaculture 6, 79-157.

Wada, K.T., Komaru, A., 1990. Inheritance of white colouration of the prismatic layer of shell in the japanese pearl oyster Pinctada fucata martensi and its importance in the pearl culture industry. Nipon Suisan Gakkaishi 56 (11), 1787-1790.

Wada, K.T., Komaru, A., 1996. Color and weight of pearls produced by grafting the mantle tissue from a selected population for white shell color of the japanese pearl oyster Pinctada fucata martensii (dunker). Aquaculture 142, 25-32. 
Figure 1. Map showing the locations of the French Polynesia Tuamotus and Gambier archipelagos. Red arrows indicate the collection site locations: Ahe, Apataki, Takaroa and Takume atolls (Tuamotu archipelago), and Mangareva Island (Gambier archipelago).

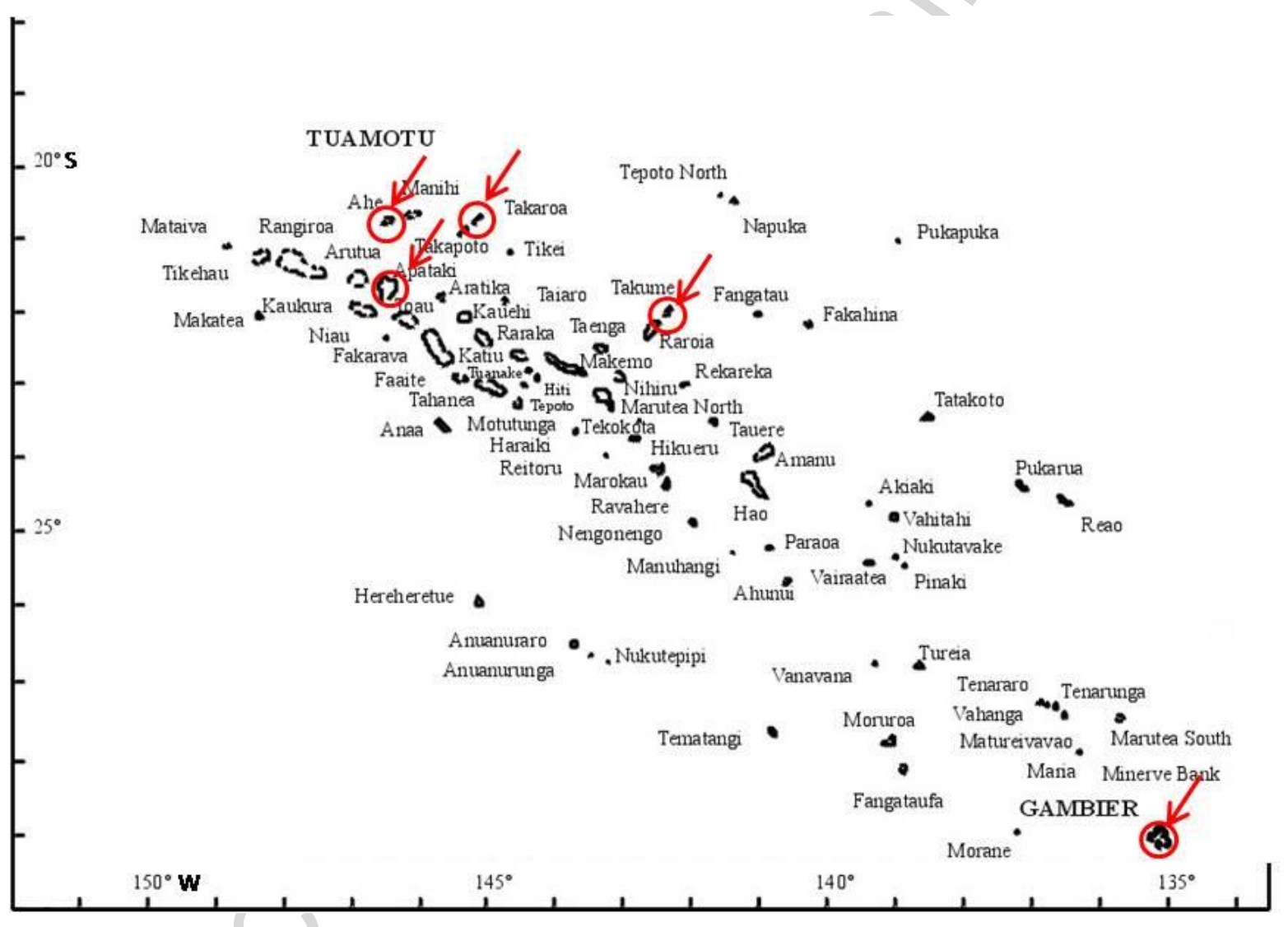


Figure 2: Shells colours of wild Pinctada margaritifera from the five main collection sites in French Polynesia (Ahe, Apataki, Takaroa, Takume atolls and Mangareva Island).

Nomenclature is given for the monochromatic and polychromatic phenotypes. First and second shell lines correspond to black and red outer shell respectively. The selected donor oysters (made by grafters) correspond to all the yellow and red inner shell base colouration phenotypes. Other inner shell phenotype corresponded to non-selected oyster and displayed a dominant grey colouration.

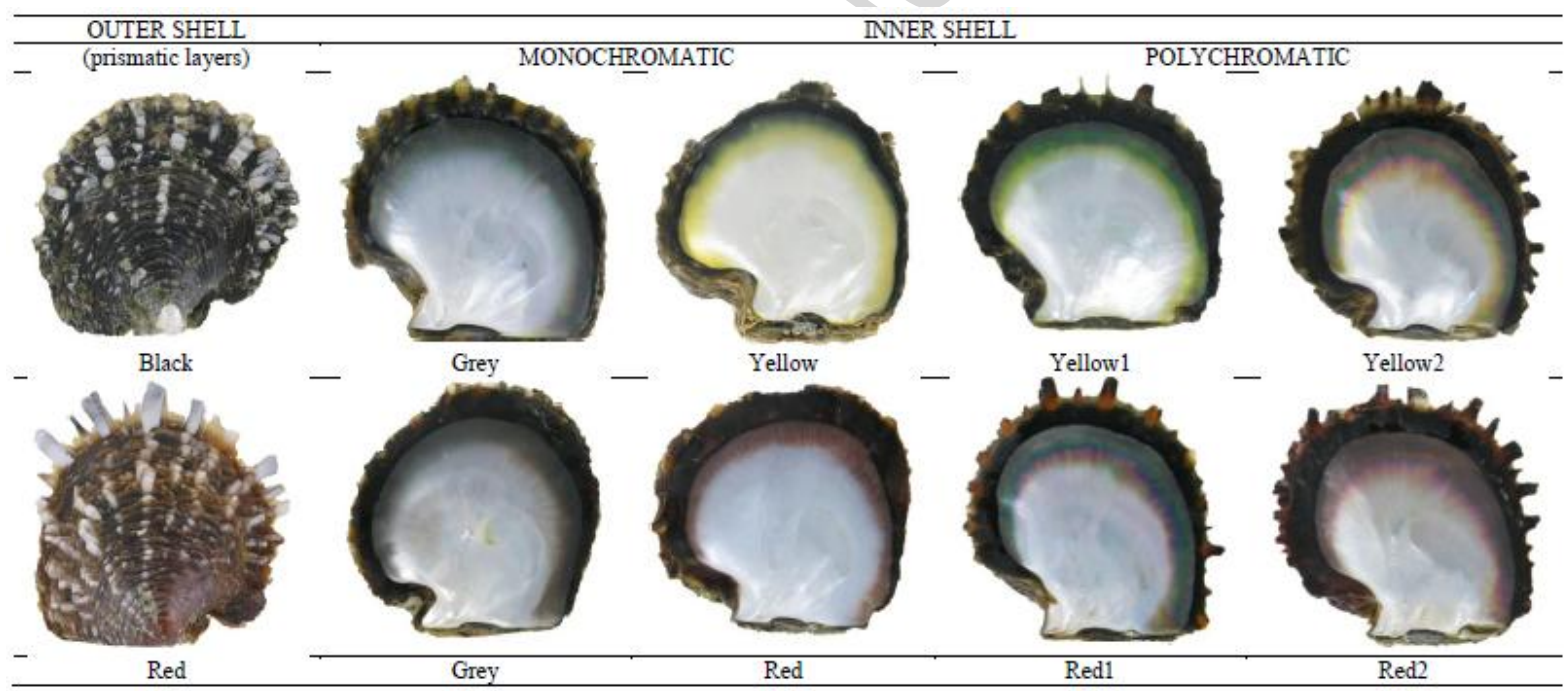


Figure 3: Correspondence between cultured Pinctada margaritifera pearl colour and inner shell colouration of the rare monochromatic phenotypes used as donors.

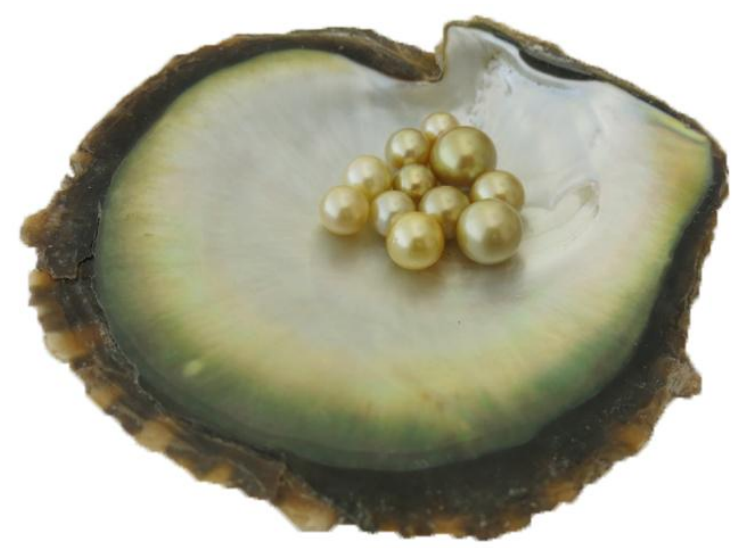

Yellow

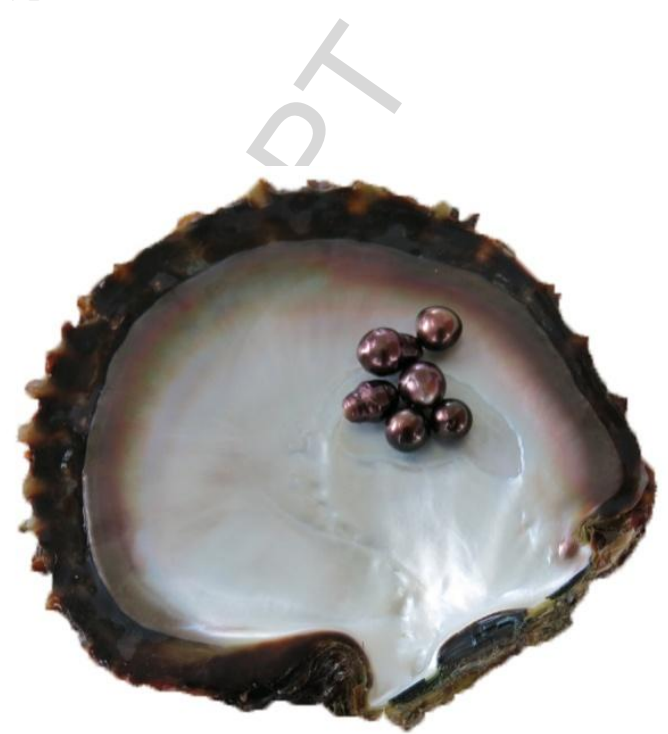

Red 
Table 1. Rates of rare inner shell colouration phenotypes of Pinctada margaritifera selected as donors from the five main collection sites in French Polynesia (Ahe, Apataki, Takaroa, Takume atolls and Mangareva Island). Oysters were provided by a pearl farm network (locations given in brackets). Data are expressed in percentages, with frequencies $(\mathrm{N})$. The data points significantly different between the locations at $p<0.05$ are indicated with letters.

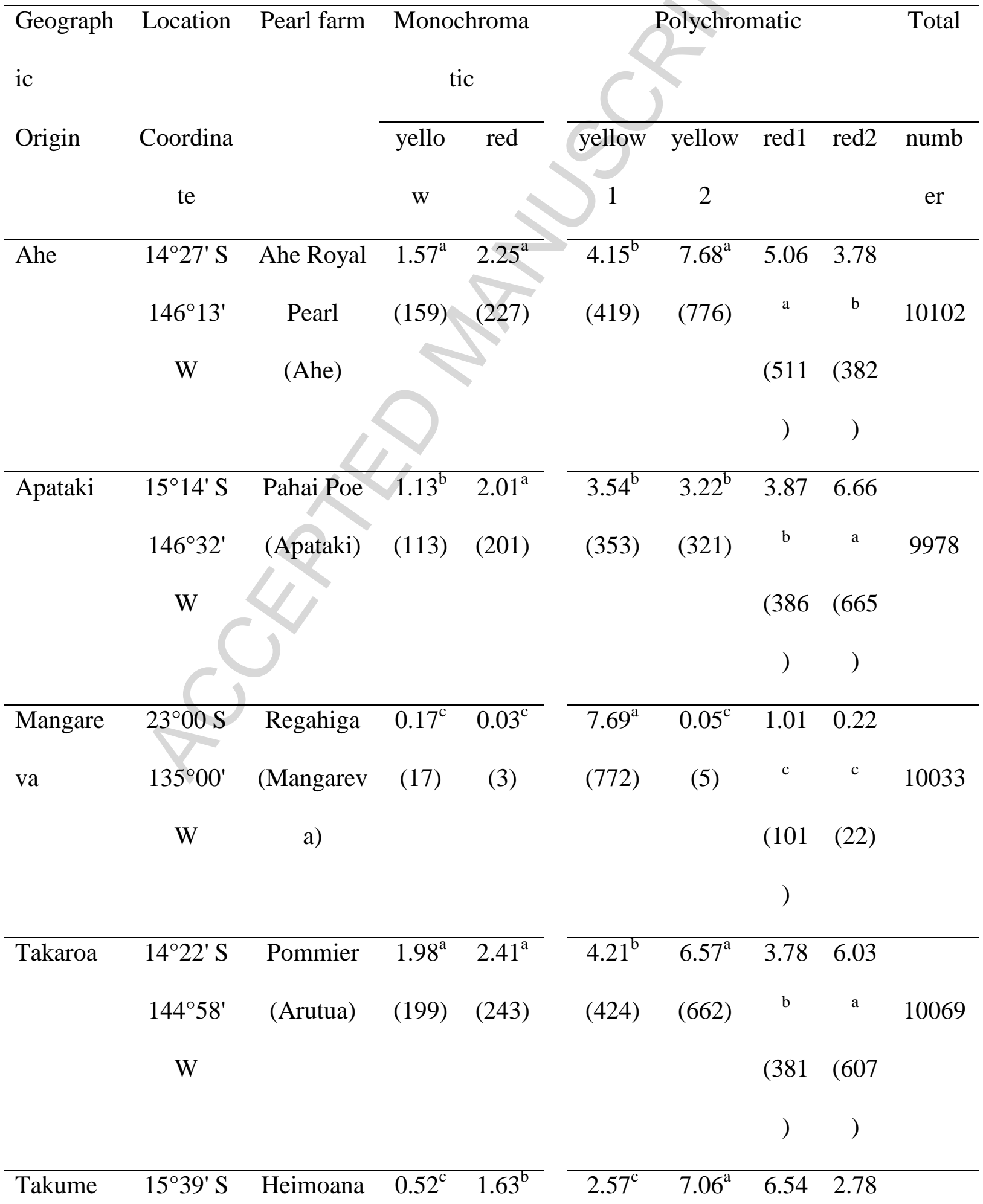




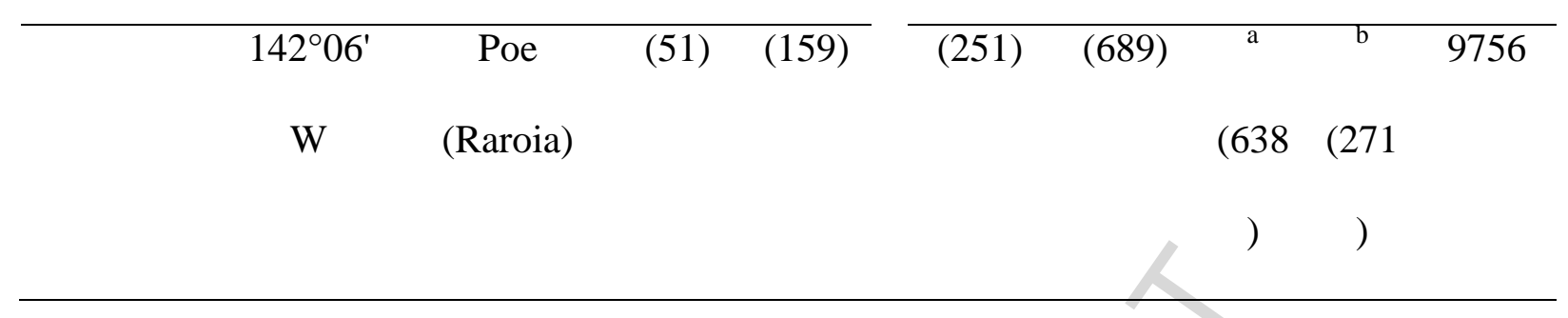


Table 2. Proportions of different pearl colour categories produced using donors of different monochromatic and polychromatic inner shell colouration phenotypes (the number of donors used is given in brackets) in Pinctada margaritifera selected from the five main collection sites in French Polynesia (Ahe, Apataki, Takaroa, Takume atolls and Mangareva island). Data are expressed in percentages, with frequencies $(\mathrm{N})$. For the polychromatic phenotypes, the data points significantly different at $p<0.05$ between the pearl colours are indicated with letters.

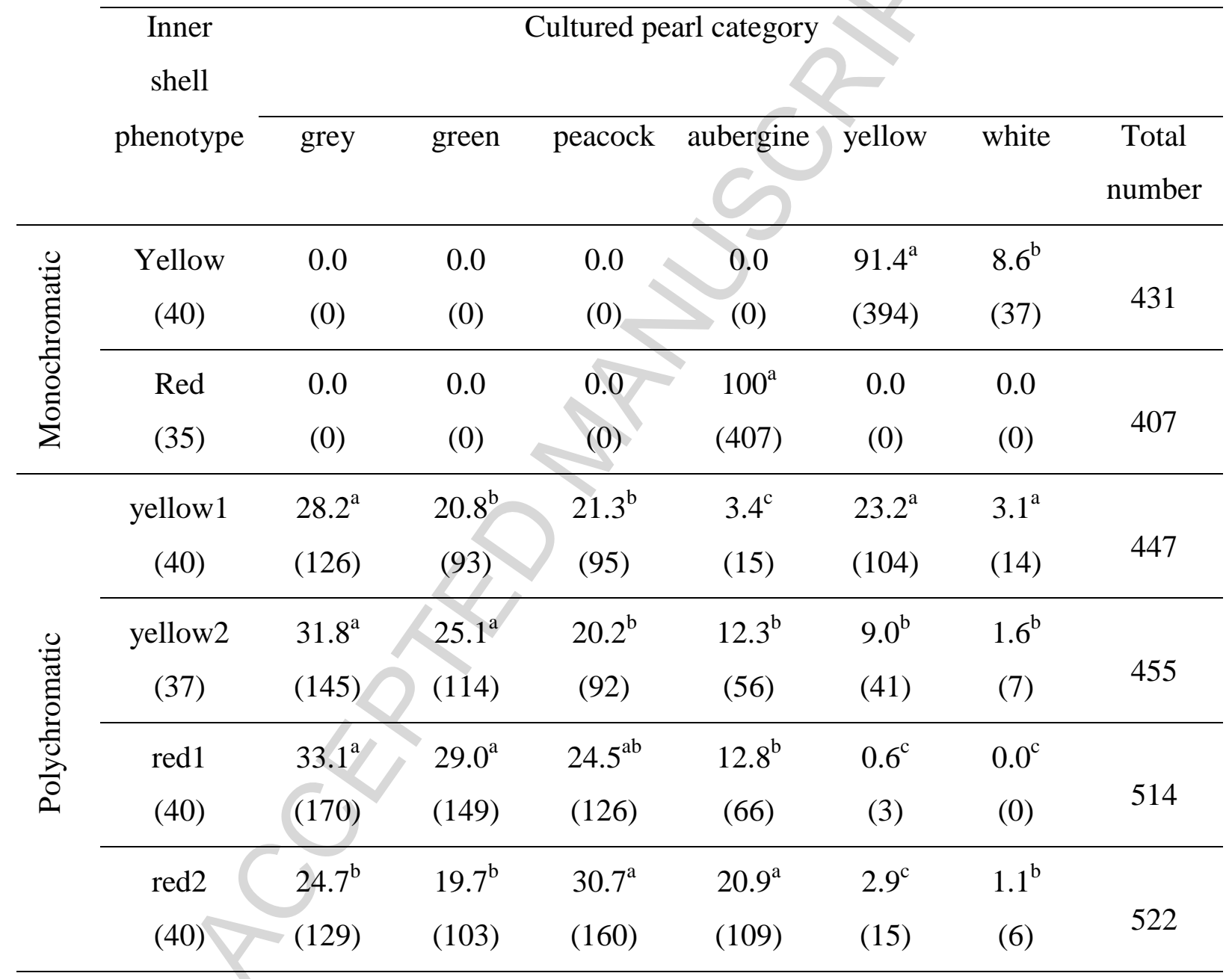

